Bloodborne Pathogens Standard on vaccination of healthcare workers with hepatitis B vaccine. Infect Control Hosp Epidemiol 1995;16:287-291.

10. Mahoney FJ, Stewart K, Hu H, Coleman P, Alter MJ. Progress toward the elimination of hepatitis $\mathrm{B}$ virus transmission among health care workers in the United States. Arch Intern Med 1997;157:2601-2605.

11. Louther J, Rivera P, Villa N, Feldman J, DeHovitz JH, Sepkowitz KA. Hepatitis B vaccination program at a New York City hospital: seroprevalence, seroconversion, and declination. Am J Infect Control 1998;26:423327.

12. Opatrný K, Farnik J, Jindra J, Valenta J, Janda J, Petera V, et al. Virová hepatitis na hemodialyzaoním stredisku. Prakt Lék 1978;58:753-756.

13. Markvart K, Lobkovic F, Vlasimská H, Pecenková I. [Antibodies against the superficial component of hepatitis B virus of health care workers] Cesk Epidemiol Mikrobiol Imunol 1978;27:327-334. Czech.

14. Farnik J, Topolcan O, Karlícek V, Honzikova J, Mlada L, Beranova I, et al. [HBS antigen and antibodies in health care workers]. Cas Lék Ces 1982;121:343-346. Czech.

15. Seycková J, Helcl J, Walter G. Prevalence of viral hepatitis among the hospital staff in CST between 1980 and 1982. J Hyg Epid (Praha) $1984 ; 28: 267-278$

16. Centers for Disease Control and Prevention. Inadequate immune response among public safety workers receiving intradermal vaccination against hepatitis B-United States, 1990-1991. MMWR 1991;40:569-572

17. Lanphear BP, Linnemann CC, Cannon CG, DeRonde MM. Decline of clinical hepatitis B in workers at a general hospital: relation to increasing vaccine-induced immunity. Clin Infect Dis 1993;16:10-14.

18. Alter MJ, Hadler SC, Margolis HS, Alexander WJ, Hu PY, Judson FN, et al. The changing epidemiology of hepatitis B in the United States. Need for alternative vaccination strategies. JAMA 1990;263:1218-1222.

19. Sikorska K, Laniec M, Buraczewska A, Hlebowicz M, Keller A, Majewska $K$. [latrogenic hepatitis $B$, non- $A$ non- $B$, and $C$ virus infections acquired in health service institutions of the Gdansk province in 1986 1995]. Przegl Epidemiol 1997;51:229-237. Polish.

20. Narendranathan M, Philip M. Reusable needles-a major risk factor for acute virus B hepatitis. Trop Doct 1993;23:64-66.

\title{
Catheter-Associated UTI Is Rarely Symptomatic
}

Gina Pugliese, RN, MS

Martin S. Favero, PhD

Catheter-associated (CA) urinary tract infection (UTI) is the most common nosocomial infection, accounting for more than 1 million cases each year in US hospitals and nursing homes. Tambyah and Maki from the University of Wisconsin Medical School at Madison conducted a study to define the clinical features of $\mathrm{CA}$ UTI. The setting was a university hospital, and the study included 1,497 newly catheterized patients. Every day that the catheter was in place, a quantitative urine culture and urine leukocyte count were obtained, and the patient was queried by a research worker regarding symptoms. To define the role of CA UTI in patients' symptoms more precisely, a subset of 1,034 patients (89 of whom developed CA UTI with more than $10^{3}$ colony-forming units/mL, who did not have another potentially confounding site of infection besides the urinary tract) was analyzed. Outcome measures were the presence of fever, symptoms commonly associated with community-acquired UTI, and peripheral leukocytosis.

There were 235 new cases of nosocomial CA UTI during the study period. More than $90 \%$ of the infected patients were asymptomatic; only 123 infections $(52 \%)$ were detected by patients' physicians using the hospital laboratory. In the subset analysis, there were no significant differences between patients with and without CA UTI in signs or symptoms commonly associated with UTI-fever, dysuria, urgency, or flank pain-or in leukocytosis. Only 1 of the 235 episodes of CA UTI that were prospectively studied was unequivocally associated with secondary bloodstream infection.

The authors conclude that, whereas CA UTIs are a major reservoir of antibiotic-resistant organisms in the hospital, they are rarely symptomatic and infrequently cause bloodstream infection. Symptoms referable to the urinary tract, fever, or peripheral leukocytosis have little predictive value for the diagnosis of CA UTI.

FROM: Tambyah PA, Maki DG. Catheter-associated urinary tract infection is rarely symptomatic: a prospective study of 1,497 catheterized patients. Arch Intern Med 2000;160:678-682. 